\title{
MODIFIED TEA LEAVES RESIDUAL FOR NICOTINE ADSORPTION
}

\author{
Y. Walid Al Bizreh ${ }^{1 a}$, Rasha Almostafa ${ }^{2 b}$ and Malak Al-Joubbeh ${ }^{3 c}$
}

\begin{abstract}
aDepartment of Chemistry, Faculty of Sciences, Damascus University, SYRIA. Email: ywbizreh2@icloud.com ${ }^{1}$ ${ }^{b}$ Department of General and Analytical Chemistry, International University for Science and Technology, SYRIA. Email: r.mostafachem@yahoo.com²

'Syrian Private University, SYRIA. Email: dr_malak.joubbeh@yahoo.com³

Corresponding author: r.mostafachem@yahoo.com
\end{abstract}

Received: $17^{\text {th }}$ Oct $2018 \quad$ Accepted: $2^{\text {nd }}$ Oct 2020

DOI: https://doi.org/10.22452/mjs.vol40no3.3

Published: $31^{\text {st }}$ Oct 2021

\begin{abstract}
In this study, boiled tea leaves residual was modified with oleum of weight $1: 1$ to prepare an adsorbent that is capable of adsorbing nicotine on its surface. The surface properties of the sample were investigated using FT-IR spectroscopy after each treatment, resulting in peaks that indicate the modification of the sample with oleum and the adsorption of nicotine on its surface. The nicotine concentration in the prepared solutions was measured using spectral analysis. The change of its adsorption was investigated based on change in time. An increase in the adsorbed amount was observed until equilibrium was reached after 24 hours. Additionally, an increase in the adsorbed amount of nicotine with an increase in its initial concentration was observed at the room temperature. The experimental data corresponded to adsorption models proposed in prior work. Besides, a mechanism of the adsorption of nicotine was suggested to occur with the participation of the two nitrogen atoms.
\end{abstract}

Keywords: nicotine, adsorption, tea, residual, oleum.

\section{INTRODUCTION}

Nicotine is an organic compound -3 (-1 methyl -2 - pyrrolidinyl) pyridine (Basher et al., 2014) that is considered to be an alkaloid. It is a highly toxic substance and is fatal when a dose reaches $40-60 \mathrm{mg}$. Compared to other alkaloids such as cocaine, which has a fatal dose of $100 \mathrm{mg} / \mathrm{kg}$ (Rakic et al., 2010), since nicotine is soluble in water, it causes environmental pollution where a large amount of nicotine is transferred to wastewater produced by tobacco treatment operations and industrial products (Maduro et al., 2007). Therefore, this waste is considered a threat to the surrounding environment and human health, and has been classified to be a toxic and hazardous substance, according to the European Union (Novotny et al., 1999). On the other hand, nicotine has recently manifested some benefits to treat certain nerve diseases, despite its concerns. This issue has imposed the necessity to extract and purify nicotine (Grozdanic et al., 2014).

Since most water purification techniques are expensive, activated carbon is used in the technique of adsorption, which is better than other methods, attributable to its simplicity and cleanliness to separate nicotine (Basher et al., 2013).

Agricultural waste has been increasingly used as an adsorbent for removing organic and inorganic contaminants. In addition, some types of natural waste, especially tea leaves and coffee remains, were used as adsorbents to remove traces of metals that exist in water, such as: treating wastewater containing traces of the metals (i.e. Lead, Mercury, 
Zinc, Copper, Nickel and Cadmium). The adsorption of the metal ions was found to follow the Langmuir isotherm equation (Utomo et al., 2007).

The ratio of removing the alkaloid materials from Indian cigarettes was also studied using low cost adsorbents from agricultural waste and industrial by- products such as bagasse, sawdust, coconut fiber and green tea leaves, whereby the ratio of their removal to these materials was $12.8 \%, \quad 10.01 \%, 12 \%$, and $13.8 \%$ respectively (Elhadi et al., 2016).

Table 1 shows the composition of tea based on dry matter percentage (Belitz et al., 2009).

Table 1. Composition (\% dry weight basis) of fresh and black tea leaves and brewed tea

\begin{tabular}{cccc}
\hline Component & Fresh & Black tea & Brewed tea \\
\hline Phenolic compounds & 30 & 5 & 4.5 \\
\hline Oxidized phenolic compounds & 0 & 25 & 15 \\
\hline Protein & 15 & 15 & traces \\
\hline Amino acids & 4 & 4 & 3.5 \\
\hline Caffeine & 4 & 4 & 3.2 \\
\hline Crude fibers & 26 & 26 & 0 \\
\hline Other carbohydrates & 7 & 7 & 4 \\
\hline Lipids & 7 & 7 & traces \\
\hline Pigments (chlorophyll and carotenoids) & 2 & 2 & traces \\
\hline Volatile compounds & 0.1 & 0.1 & 0.1 \\
\hline Minerals & 5 & 5 & 4.5 \\
\hline
\end{tabular}

\section{THE GOAL OF THE WORK}

This work aims to preparing an adsorbent (BTLS) from modification with the oleum of the surface of boiled tea leaves (BTLs) residual for:

- Using the adsorbent (BTLs) for nicotine adsorption from its aqueous solutions;

- Using domestic waste to eliminate environmental contaminants; and

- Studying the surface properties of (BTLS) by using FT-IR spectroscopy.

\section{MATERIALS}

- $\quad$ BTLs residual, local waste.

- Nicotine $\mathrm{C}_{10} \mathrm{H}_{14} \mathrm{~N}_{2}, \quad \mathrm{M}_{\mathrm{w}}=162.24$ $\mathrm{g} / \mathrm{mol}$, purity $>99 \%$, Merck.

- $\quad$ Sulfuric acid $\mathrm{H}_{2} \mathrm{SO}_{4}, 98 \%$, SDFCL.

- Oleum $\mathrm{H}_{2} \mathrm{~S}_{2} \mathrm{O}_{7}$, Homs Refinery.

- Barium chloride $\mathrm{BaCl}_{2} \cdot 2 \mathrm{H}_{2} \mathrm{O}, \mathrm{M}_{\mathrm{w}}=$ $244.27 \mathrm{~g} / \mathrm{mol}$, purity $99 \%$.

- Sodium hydroxide $\mathrm{NaOH}$, $\mathrm{M}_{\mathrm{w}}=40 \mathrm{~g} / \mathrm{mol}$, purity $98-100 \%$, Panareak.

- Acetic acid $\mathrm{CH}_{3} \mathrm{COOH}$, $\mathrm{M}_{\mathrm{w}}=60 \mathrm{~g} / \mathrm{mol}$, purity $99.5-100 \%$, Panareak. 


\section{EQUIPMENTS AND TOOLS}

- Spectrophotometer UV-VIS: T 80+ UV / VIS spectrometer PG instruments LTD.

- Spectroscopy Fourier Transform infrared Spectrometer Jusco FT-IR4200

- Centrifuge J.P.SELECTA, 7002240,230 V, 50/60 HZ, 100W Thermostat T LAUD

- Oven drying $\mathrm{K} \& \mathrm{H}$ industries, Damascus, Syria

- Furnace industries, K \& H, serial NO: 030509.watt max: 3000W, Volt: 220v, HZ: 50

- Delicate balance: Sartorius ED 2245, Max: $22 \mathrm{~g}, \mathrm{~d}=0.1 \mathrm{mg}$.

\section{THE SAMPLE PREPARATION}

\subsection{Determination of the nature of surface}

The residual surface of BTLs was activated with oleum, due to the presence of alkaline centers on its surface that impede nicotine adsorption. It was shown by soaking $0.5 \times 10^{-3} \mathrm{~kg}$ of BTLs residual in $10 \mathrm{ml}$ of acetic acid $(0.0555 \mathrm{M})$ for three days. The acid concentration was $0.04545 \mathrm{M}$ after soaking. The number of alkaline centers on the surface of BTLs residual was calculated by means of the difference between acid concentrations before and after soaking it with the BTLs residual $\left(1.21 \times 10^{23}\right.$ alkaline center $\left./ \mathrm{kg}\right)$.

\subsection{Modification of (BTL) residual}

The surface of the sample was activated with oleum. It was put in a flask, and oleum was added slowly with a ratio of $1: 1$. Next, the mixture was connected to washing bottles. It was isolated for 24 hours. The mixture was then placed on a filter paper and washed with distilled water to ensure that all the sulfates were removed from the filtrate. It was then dried after weighing it at a temperature of $373 \mathrm{~K}$, until it reached a stable weight. The new prepared sample was referred to as BTLs.

\section{DETERMINATION OF NICOTINE BY SPECTROPHOTOMETRY}

A standardized series of nicotine solutions were prepared at various concentrations and diluted with sulfuric acid $(0.025 \mathrm{M})$. Each solution in a quartz cuvette was measured against a blank sample containing a sulfuric acid solution (AlBizreh et al., 1999). Spectral scanning was set to be in the range of 200-400nm of $\mathrm{UV}$, in order to determine the maximum wave length for measuring the absorbance of the solutions of the standardized series ( $\lambda_{\max }=258 \mathrm{~nm}$ ), as shown in Figure (1).

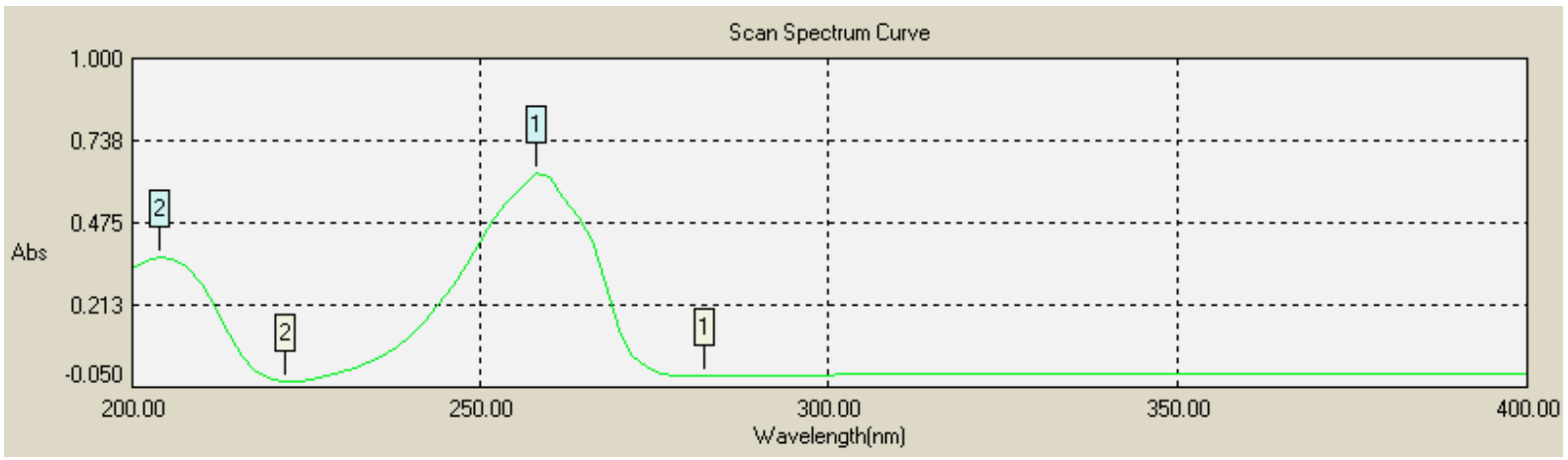

Figure 1. Spectral scan of the studied nicotine solution 
Then, the absorbance of the standardized series solutions was measured at the maximum wave length that was experimentally determined. Figure (2) shows that the linearity of the standardized curve was $\mathrm{R}^{2}=0.999$, which was used for determining the unknown concentrations of nicotine solutions.

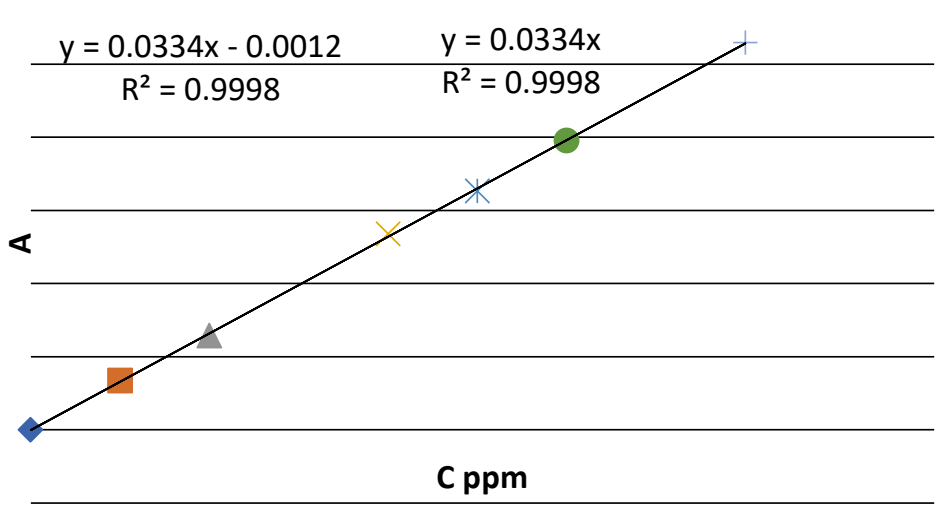

Figure 2. Change of the solution absorbance with a change of the nicotine solution concentration

\section{RESULTS AND DISCUSSION}

7.1 The study of the kinetics of nicotine adsorption on the modified boiled tea leaves residual with change in time
The change of the nicotine concentration was studied after soaking $0.05 \times 10^{-3} \mathrm{~kg}$ of the adsorbent material in $5 \times 10^{-3} \mathrm{~L}$ of nicotine solution at various times. Table (2) shows the change in the adsorbed nicotine amount with change in time.

Table 2. The change of adsorbed nicotine amount with the change of time

\begin{tabular}{cccccc}
\hline time (h) & $\mathbf{C}_{\mathbf{e}}(\mathbf{m m o l} / \mathbf{L})$ & $\mathbf{a}(\mathbf{m m o l} / \mathbf{k g})$ & $\mathbf{L n}(\mathbf{a e}-\mathbf{a})$ & $\mathbf{t} / \mathbf{a}$ & $\mathbf{t}^{\mathbf{1} \mathbf{2}}$ \\
\hline 2 & 4.8222 & 127.959 & 4.5306 & 0.0156 & $\mathbf{1 . 4 1 4}$ \\
\hline 4 & 4.7416 & 136.021 & 4.4397 & 0.0294 & $\mathbf{2 . 0 0 0}$ \\
\hline 6 & 4.5740 & 152.786 & 4.2193 & 0.0393 & $\mathbf{2 . 4 4 9}$ \\
\hline 8 & 4.2917 & 181.016 & 3.6828 & 0.0442 & $\mathbf{2 . 8 2 8}$ \\
\hline 10 & 4.2396 & 186.218 & 3.5425 & 0.0537 & $\mathbf{3 . 1 6 2}$ \\
\hline 12 & 4.2032 & 189.867 & 3.4309 & 0.0632 & $\mathbf{3 . 4 6 4}$ \\
\hline 14 & 4.1864 & 191.543 & 3.3751 & 0.0731 & $\mathbf{3 . 7 4 2}$ \\
\hline 16 & 4.1208 & 198.102 & 3.1211 & 0.0808 & $\mathbf{4 . 0 0 0}$ \\
\hline 18 & 3.9524 & 214.941 & 1.7632 & 0.0837 & $\mathbf{4 . 2 4 3}$ \\
\hline 20 & 3.9413 & 216.050 & 1.5522 & 0.0926 & $\mathbf{4 . 4 7 2}$ \\
\hline 22 & 3.9024 & 219.946 & -0.1909 & 0.1000 & $\mathbf{4 . 6 9 0}$ \\
\hline 24 & 3.8941 & 220.772 & - & 0.1087 & $\mathbf{4 . 8 9 9}$ \\
\hline
\end{tabular}


where $a_{\mathrm{e}}=220.772 \mathrm{mmol} / \mathrm{kg}$ is the experimental adsorbed nicotine amount at the equilibrium stage, a is the adsorbed nicotine amount at time $\mathrm{t}(\mathrm{mmol} / \mathrm{kg}), \mathrm{C}_{\mathrm{e}}$ is the equilibrium nicotine concentration $(\mathrm{mmol} / \mathrm{L}), \mathrm{t}$ is the time of soaking $(\mathrm{h})(1 \mathrm{~h}=$ 3,600 seconds).

\subsubsection{Determination of the limiting} step for nicotine adsorption by studying the adsorption kinetic on BTLs with change in time, according to the equation for Intra-particle diffusion

$$
\begin{aligned}
& \text { The intra-particle } \begin{array}{c}
\text { diffusion } \\
\text { equation was applied } \\
\text { al., 1963): }
\end{array} \\
& \qquad \mathrm{a}=\mathrm{k} \mathrm{t}^{1 / 2}+\mathrm{C}
\end{aligned}
$$

where $\mathrm{k}$ represents the intra-particle diffusion rate constant, and $\mathrm{C}$ is a constant. Figure (3) shows the change of the adsorbed nicotine amount with change in contact time, according to equation (1).

\section{$\mathrm{t} 1 / 2$}

Figure 3. Change of adsorbed nicotine amount with change in contact time

As shown in Figure (3), there is an acceptable conformity of the experimental data with the intra-particle diffusion equation (1), where the determined values of $\mathrm{k}$ and $\mathrm{C}$ according to Figure (3) are $\left(\mathrm{k}=28.42 \mathrm{mmol} \cdot \mathrm{h}^{-1 / 2} / \mathrm{kg}\right.$ and $\left.\mathrm{C}=88.27\right)$. It can also be observed that the intra-particle diffusion is the main limiting step, in addition to a partial chemical adsorption participation.

\subsubsection{The change of nicotine equilibrium} concentration with change in time, according to the pseudo first-order and pseudo second-order models
Applying the pseudo first-order model for studying the kinetics of adsorption according to the Lagergren equation (2) (Lagergren et al., 1998):

$$
\operatorname{Ln}\left(\mathrm{a}_{\mathrm{e}}-\mathrm{a}\right)=\operatorname{Ln} \mathrm{a}_{1 \mathrm{e}}-\mathrm{k}_{1} \mathrm{t}
$$

where $\mathrm{k}_{1}$ represents the kinetics constant of the pseudo first-order $\left(\mathrm{h}^{-1}\right)$, and $\mathrm{a}_{1 \mathrm{e}}$ is the theoretical amount of adsorbed nicotine according to the pseudo first-order. Figure (4) clarifies the change of $\operatorname{Ln}\left(\mathrm{a}_{\mathrm{e}}-\mathrm{a}\right)$ with change in the contact time, according to the Lagergren equation (2). 


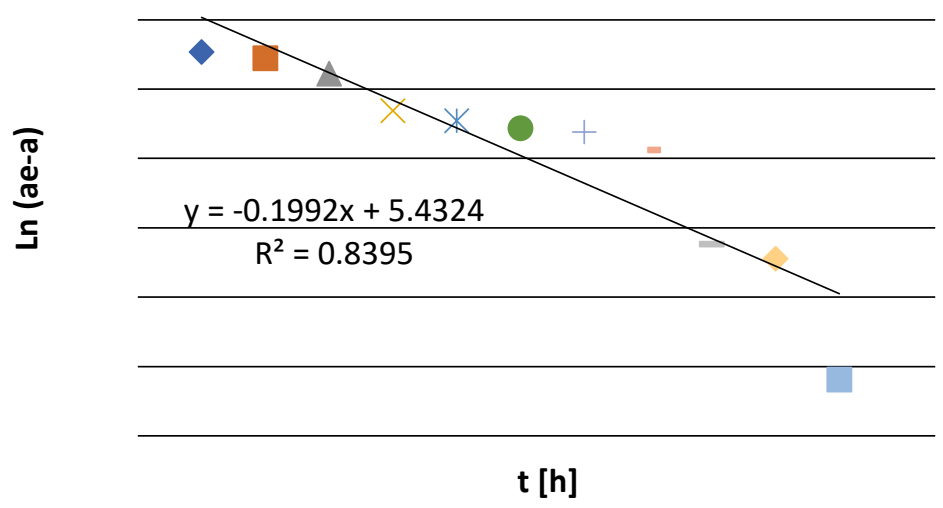

Figure 4. Change of $\operatorname{Ln}\left(a_{e}-a\right)$ with change in the contact time

Applying the pseudo second-order model for studying the kinetics of the interaction according to equation (3) (Ho et al., 2000):

$$
\mathrm{t} / \mathrm{a}=1 /\left(\mathrm{k}_{2} \mathrm{a}_{2 \mathrm{e}} \mathrm{e}^{2}\right)+\left(1 / \mathrm{a}_{2 \mathrm{e}}\right) \mathrm{t}
$$

where $\mathrm{k}_{2}$ is the kinetics constant of the pseudo second-order $\left(\mathrm{kgmmol}^{-1} \cdot \mathrm{h}^{-1}\right)$, and $\mathrm{a}_{2 \mathrm{e}}$ is the theoretical amount of adsorbed nicotine according to the pseudo secondorder. Figure (5) clarifies the change of $t / a$ with the change in the contact time, according to equation (3) (Ho et al., 2000).

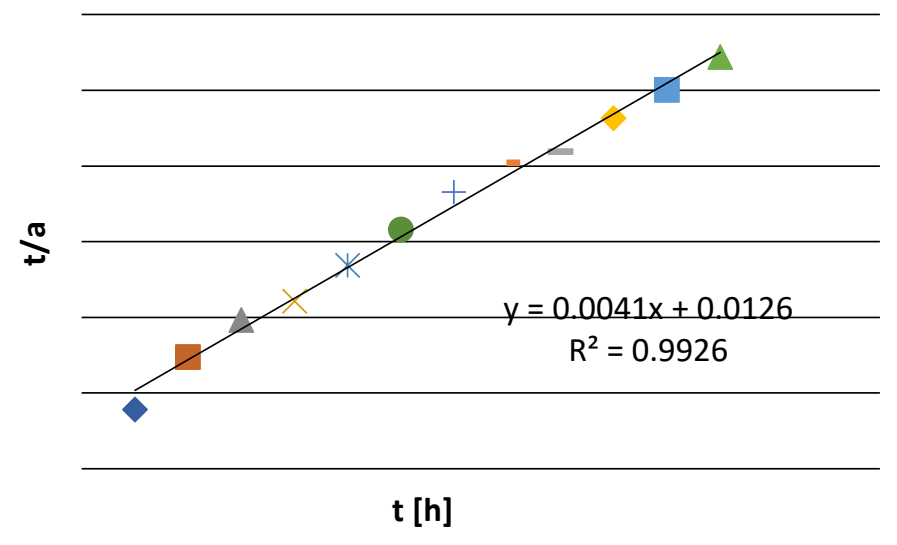

Figure 5. Change of t/a with change in the contact time

It is noticed in Figure (4) that there is an insufficient conformity of the pseudo first-order model, according to the Lagergren equation, because of the decreasing in $\mathrm{R} 2$ value. It is noticed in Figure (5) that there is a good conformity of the pseudo second-order model according to equation (3), where $\mathrm{a}_{2 \mathrm{e}}=250 \mathrm{mmol} / \mathrm{kg}$ and $\mathrm{k}_{2}=0.0013 \mathrm{~kg} \cdot \mathrm{mmol}^{-1} \cdot \mathrm{h}^{-1}$.
7.2. Study of the change of the adsorbed amount with change in the initial concentration of nicotine on BTLs at room temperature

The change of the adsorbed amount of nicotine was measured based on change in the initial concentration after soaking $0.05 \times 10-3 \mathrm{~kg}$ of the adsorbent material in $5 \mathrm{ml}$ of the prepared nicotine solution for 24 hours, at $293 \mathrm{~K}$. The results are shown in Table (3). 
Table 3. Change in nicotine equilibrium concentration at $293 \mathrm{~K}$

\begin{tabular}{ccccccc}
\hline $\mathrm{C}_{0}$ & $1 / \mathrm{C}_{\mathrm{e}}$ & $\mathrm{a}$ & $\log \mathrm{C}_{\mathrm{e}}$ & $1 / \mathrm{a}$ & $\log \mathrm{a}$ & $\operatorname{Ln} \mathrm{C}_{\mathrm{e}}$ \\
\hline 0.6484 & 2.6308 & 26.8121 & -0.4201 & 0.0373 & 1.4283 & $\mathbf{- 0 . 9 6 7 3}$ \\
\hline 1.3591 & 1.2487 & 55.7816 & -0.0964 & 0.0179 & 1.7465 & $\mathbf{- 0 . 2 2 2 1}$ \\
\hline 1.7197 & 1.1118 & 81.9773 & -0.0460 & 0.0122 & 1.9137 & $\mathbf{- 0 . 1 0 6 0}$ \\
\hline 2.3097 & 0.6912 & 86.2919 & 0.1604 & 0.0116 & 1.9360 & $\mathbf{0 . 3 6 9 3}$ \\
\hline 2.9518 & 0.5486 & 112.8575 & 0.2608 & 0.0089 & 2.0525 & $\mathbf{0 . 6 0 0 5}$ \\
\hline 3.6466 & 0.4472 & 141.0873 & 0.3495 & 0.0071 & 2.1495 & $\mathbf{0 . 8 0 4 7}$ \\
\hline 4.2120 & 0.3880 & 163.4615 & 0.4112 & 0.0061 & 2.2134 & $\mathbf{0 . 9 4 6 7}$ \\
\hline 4.7837 & 0.3380 & 182.5074 & 0.4710 & 0.0055 & 2.2613 & $\mathbf{1 . 0 8 4 6}$ \\
\hline 5.3501 & 0.2965 & 197.6701 & 0.5280 & 0.0051 & 2.2959 & $\mathbf{1 . 2 1 5 8}$ \\
\hline 5.6913 & 0.2699 & 198.5947 & 0.5688 & 0.0050 & 2.2980 & $\mathbf{1 . 3 0 9 7}$ \\
\hline
\end{tabular}

where $\mathrm{C}_{0}$ represents the initial concentration of nicotine solution $(\mathrm{mmol} / \mathrm{L}), \mathrm{C}_{\mathrm{e}}$ is the equilibrium nicotine concentration $(\mathrm{mmol} / \mathrm{L})$, and $\mathrm{a}$ is the adsorbed nicotine amount at time $\mathrm{t}$ ( $\mathrm{mmol} / \mathrm{kg})$.

\subsection{The adsorption models application}

\subsubsection{Study of the results according to Langmuir equation}

The previous results are represented diagrammatically according to the Langmuir equation axis in Figure (6).

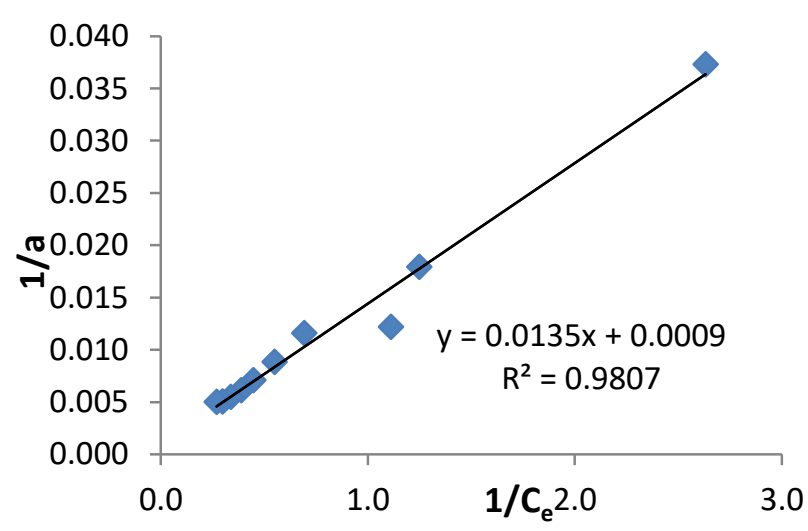

Figure 6. Change of nicotine equilibrium concentration according to the Langmuir equation axis at the room temperature

It is noticed in Figure (6) that there is an acceptable conformance of the results with the Langmuir equation (4) (Dada et al., 2012):

$$
\theta=\mathrm{a} / \mathrm{a}_{\mathrm{m}}=\left(\mathrm{K}_{\mathrm{L}} \mathrm{C}_{\mathrm{e}}\right) /\left(1+\mathrm{K}_{\mathrm{L}} \mathrm{C}_{\mathrm{e}}\right) \longrightarrow \mathrm{a}=\left(\mathrm{K}_{\mathrm{L}} \mathrm{a}_{\mathrm{m}} \mathrm{C}_{\mathrm{e}}\right) /\left(1+\mathrm{K}_{\mathrm{L}} \mathrm{C}_{\mathrm{e}}\right) 1 / \mathrm{a}=1 /\left(\mathrm{K}_{\mathrm{L}} \mathrm{a}_{\mathrm{m}} \mathrm{C}_{\mathrm{e}}\right)+1 / \mathrm{a}_{\mathrm{m}}
$$

where $\mathrm{C}_{\mathrm{e}}$ represents the equilibrium concentration of the solution $(\mathrm{mmol} / \mathrm{L})$, $\mathrm{a}$ is the adsorbed amount that is retained on the adsorbent $(\mathrm{mmol} / \mathrm{kg}), \mathrm{a}_{\mathrm{m}}$ is the adsorbed amount that is retained on the adsorbent when it forms a monolayer $(\mathrm{mmol} / \mathrm{kg}$ ), and $\mathrm{K}_{\mathrm{L}}$ is Langmuir's adsorption coefficient ( $\mathrm{L}$. $\left.\mathrm{mmol}^{-1}\right)$. The values of the adsorption 
dimensions according to the Langmuir equation at room temperature were $\mathrm{a}_{\mathrm{m}}=$ $1111.11 \mathrm{mmol} / \mathrm{kg}$ and $\mathrm{K}_{\mathrm{L}}=0.0666 \mathrm{~L} / \mathrm{mmol}$.
Basher (2014) verified the adsorption of nicotine from an aqueous solution by using coconut fiber, sawdust and tea leaves waste as adsorbents; the results are shown in Table (4).

Table 4. the best adsorbed amounts of nicotine on the studied adsorbents [1]

\begin{tabular}{ccc}
\hline Adsorbent & $\mathrm{a}_{\mathrm{m}}[\mathrm{mg} / \mathrm{g}]$ & $\mathrm{a}_{\mathrm{m}}[\mathrm{mmol} / \mathrm{kg}]$ \\
\hline Coconut fiber & 2.04 & $\mathbf{1 2 . 5}$ \\
\hline Sawdust & 1.88 & $\mathbf{1 1 . 5}$ \\
\hline Tea leaves waste & 0.80 & $\mathbf{4 . 9}$ \\
\hline
\end{tabular}

When comparing the results in Table (4) to those achieved by this study, a higher adsorption of nicotine was observed on the BTLs modified with oleum, which leads to an increase in the effective centers on the modified adsorbent surface (BTLs).

\subsubsection{Study of the results according to the Freundilch equation}

Figure (7) depicts the previous experimental data diagrammatically, according to the Freundlich equation axis.

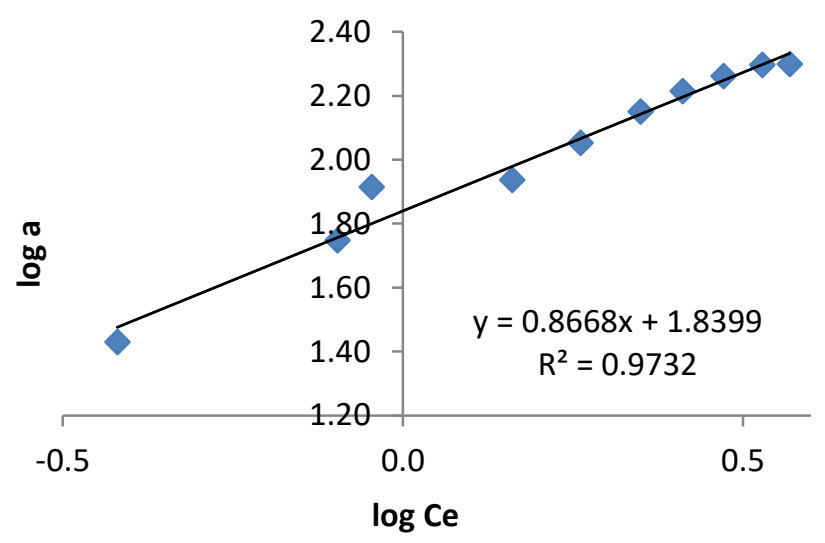

Figure 7. Change of nicotine equilibrium concentration according to the Freundlich equation axis at the room temperature

Figure (7) shows an acceptable applicability of the Freundlich equation when the initial concentration of the nicotine changed in the solution. Ghiaci expressed the Freundlich equation (5) (Ghiaci et al., 2004) as follows:

$$
\begin{gathered}
a=K_{f} \cdot C_{e} e^{1 / n} \\
\log a=1 / n \log C_{e}+\log K_{f}
\end{gathered}
$$

where $\mathrm{C}_{\mathrm{e}}$ represents the equilibrium concentration of the solution $(\mathrm{mmol} / \mathrm{L})$, $\mathrm{a}$ is the adsorbed amount that is retained on the adsorbent $(\mathrm{mmol} / \mathrm{kg}), \mathrm{K}_{\mathrm{f}}, \mathrm{n}$ and represents the Freundlich coefficients. The values of the adsorption dimensions according to the Freundlich equation at the room temperature were $n=1.153$ and $K_{f}=69.167$ $\mathrm{lit}^{1 / \mathrm{n}} /\left[\mathrm{kg} .(\mathrm{mmol})^{(1-\mathrm{n}) / \mathrm{n}}\right]$.

\subsubsection{Study of the results according to Temkin equation}

Figure (8) depicts the previous results diagrammatically according to the Temkin equation axis. 


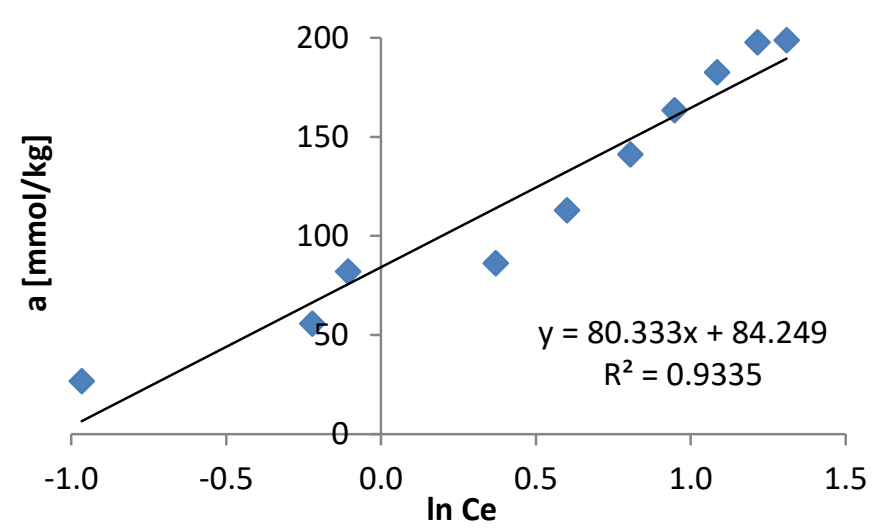

Figure 8. Change of adsorbed nicotine amount according to the Temkin equation axis at the room temperature

It is noticed in Figure (8) that there is an acceptable applicability of the Temkin equation with a change of the adsorbed nicotine amount, with a change in the initial nicotine concentration in the solution, where the Temkin equation (6) (Dada et al., 2012) was defined as follows:

$$
\mathrm{a}=\mathrm{B} \operatorname{Ln} \mathrm{A}_{\mathrm{T}}+\mathrm{B} \mathrm{LnC}_{\mathrm{e}}
$$

where $\mathrm{C}_{\mathrm{e}}$ represents the equilibrium concentration of the solution $(\mathrm{mmol} / \mathrm{L})$, a is the adsorbed amount that is retained on the adsorbent $(\mathrm{mmol} / \mathrm{kg}), \mathrm{B}$ is a constant related to the heat of adsorption $\left(\mathrm{B}=\mathrm{RT} / \mathrm{b}_{\mathrm{T}}\right)$, and $\mathrm{b}$,
$\mathrm{A}_{\mathrm{T}}$ represents the Temkin coefficients. The values of the adsorption dimensions according to the Temkin equation at the room temperature were $\mathrm{B}=80.333 \mathrm{~J} / \mathrm{mol}, \mathrm{A}_{\mathrm{T}}$ $=2.854 \mathrm{~L} / \mathrm{kg}$ and $\mathrm{b}_{\mathrm{T}}=30.323$.

\subsection{Comparing the results to prior works}

Table (5) shows a comparison between the nicotine adsorption results for the modified oleum compressed coffee residuals (AlBizreh et al., 2017) and the date seed carbon modified with oleum (Almostafa et al., 2017), with the results in this study.

Table 5. Nicotine adsorption results for the modified compressed coffee residual and modified date seed carbon with the results obtained by BTLs

\begin{tabular}{|c|c|c|c|c|c|c|c|c|}
\hline \multirow{2}{*}{ Adsorbent } & \multicolumn{3}{|c|}{ Temkin Constants } & \multicolumn{2}{|c|}{$\begin{array}{l}\text { Freundlich } \\
\text { Constants }\end{array}$} & \multicolumn{2}{|c|}{$\begin{array}{l}\text { Langmuir } \\
\text { Constants }\end{array}$} & \multirow{2}{*}{$\begin{array}{c}\text { Removal } \\
\text { Percentage } \\
\%\end{array}$} \\
\hline & $\mathrm{b}_{\mathrm{T}}$ & $\mathrm{B}$ & $\mathrm{A}_{\mathrm{T}}$ & $\mathrm{K}_{\mathrm{f}}$ & $\mathrm{n}$ & $\mathrm{K}_{\mathrm{L}}$ & $a_{m}$ & \\
\hline $\begin{array}{c}\text { Modified } \\
\text { compressed } \\
\text { coffee residuals } \\
\text { [albizreh et al., } \\
2017 \text { ] }\end{array}$ & 37.08 & 61.4 & 2.12 & 40.20 & 1.1 & 0.151 & 322.5 & $26.3 \%$ \\
\hline $\begin{array}{l}\text { Modified date } \\
\text { seed carbon } \\
\text { [almostafa et al., } \\
\text { 2017] }\end{array}$ & 71.02 & 34.5 & 29.5 & 106.9 & 3.0 & 2.90 & 163.9 & $24.11 \%$ \\
\hline $\begin{array}{l}\text { Modified tea } \\
\text { leaves residual }\end{array}$ & 30.32 & 80.3 & 2.8 & 69.16 & 1.1 & 0.066 & 1111 & $34.9 \%$ \\
\hline
\end{tabular}


Table (5) shows that the removal percentage of nicotine from aqueous solutions on BTSs residual modified with oleum is higher than that of the modified compressed coffee residual. It is also higher than that of the modified date seed carbon.

\subsection{Results of the FT-IR spectroscopy}

The infrared spectrum (FT-IR) of the (BTLs) residual was studied, and the results of the spectrum are shown in Figure (9).

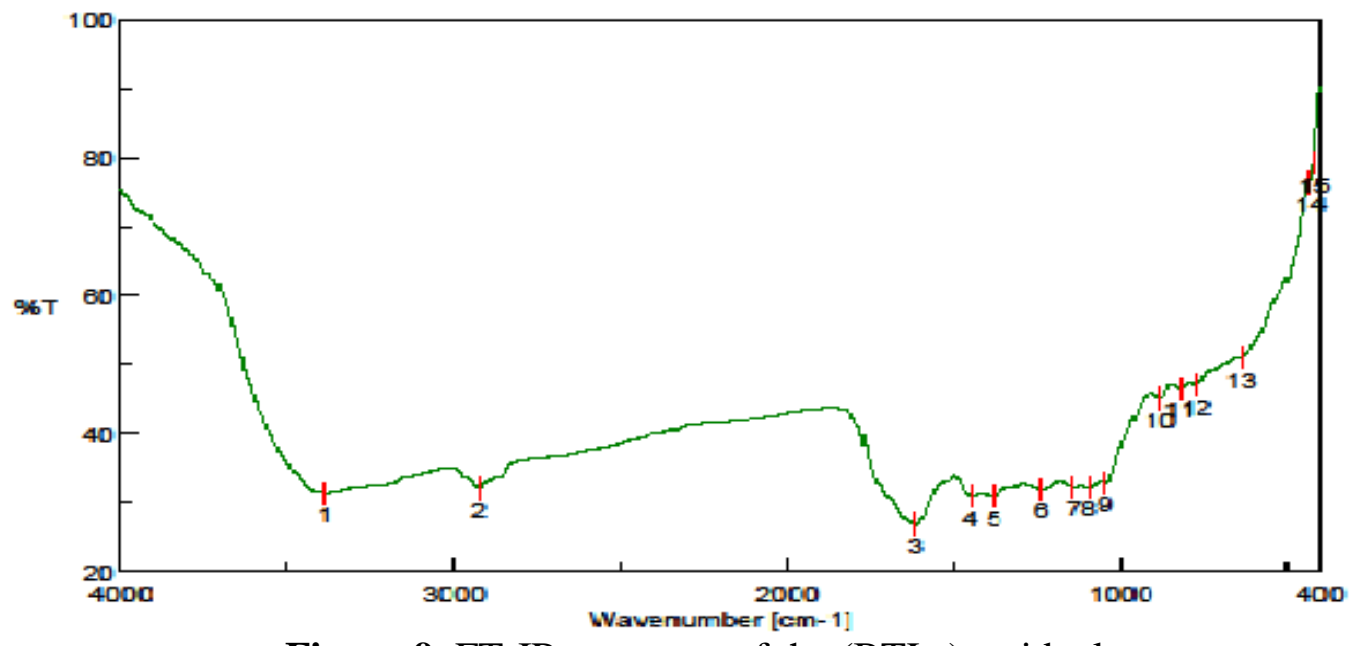

Figure 9. FT-IR spectrum of the (BTLs) residual

The effective functional groups in Table (6) indicate the presence of amino compounds involved in the composition of tea, without any treatment. Carbon and nitrogen groups may be related to the presence of organic compounds i.e. (proteins) in the chemical composition of tea leaves (Adnan, 2013).

Table 6. Effective functional groups of BTLs (Kzitcina et al., 1979)

\begin{tabular}{cccc} 
Group & Number & The Wave Number $\mathbf{C m}^{-\mathbf{1}}$ & Intensity \\
\hline$-\mathrm{NH}$ & 1 & 3384.46 & $\mathbf{3 . 1 3}$ \\
\hline$-\mathrm{CH}$ & 2 & 2924.52 & $\mathbf{3 . 2 1}$ \\
\hline $\begin{array}{c}\mathrm{C}=\mathrm{O} \\
-\mathrm{NH}\end{array}$ & 3 & 1616.06 & $\mathbf{2 . 6 8}$ \\
\hline $\mathrm{NO}_{2}{ }^{+}$ & 5 & 1380.78 & $\mathbf{3 . 1 0}$
\end{tabular}

Figure 10 shows the results of the spectrum of BTLs residual after modification with oleum. 


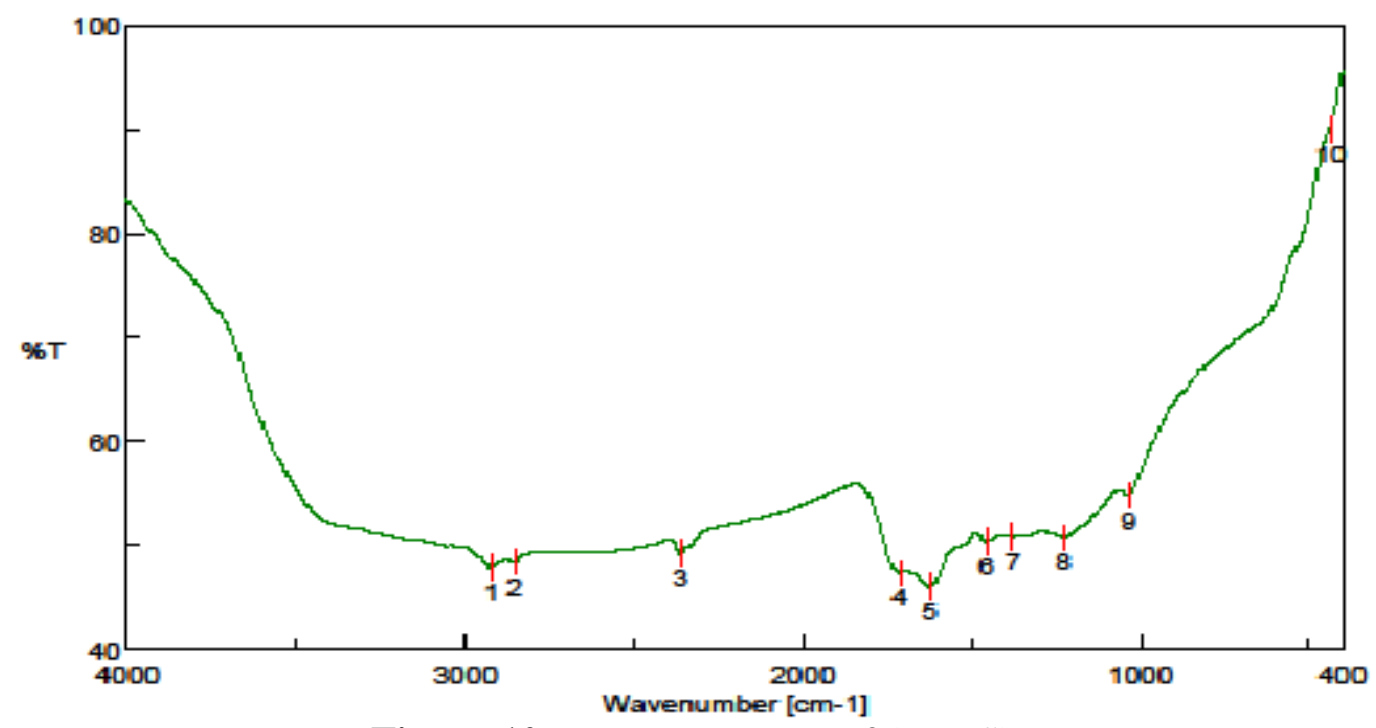

Figure 10. FT-IR spectrum of (BTLS)

Table (7) clarifies the effective functional groups $\left(\mathrm{NH}_{3}{ }^{+}, \mathrm{RSO}_{3} \mathrm{H}, \mathrm{HSO}_{4}{ }^{-}\right.$ and $\mathrm{S}=\mathrm{O}$ ) that indicate the modification with oleum of the surface of the BTLs residual, and that is by protonation of the amino groups existing in the tea leaves. The nitrogen groups may belong to the original sample composition.

Table 7. Effective functional groups in FT-IR spectrum of BTLs (Kzitcina et al., 1979)

\begin{tabular}{cccc} 
Group & Number & The wave number $\mathbf{c m}^{-1}$ & Intensity \\
\hline$-\mathrm{CH}$ & 1 & 2922.59 & $\mathbf{4 . 7 9}$ \\
& 2 & 2855.1 & $\mathbf{4 . 8 4}$ \\
\hline $\mathrm{NH}_{3}{ }^{+}$ & 3 & 2363.34 & $\mathbf{4 . 9 2}$ \\
$\mathrm{C}=\mathrm{O}$ & 4 & 1710.55 & $\mathbf{4 . 7 4}$ \\
\hline$-\mathrm{NH}_{2}$ & & & \\
\hline & 5 & 1622.8 & $\mathbf{4 . 6}$ \\
$-\mathrm{CH}_{2}$ & & & $\mathbf{5 . 0 4}$ \\
\hline $\mathrm{S}=\mathrm{O}^{-}$ & 6 & 1455.03 & $\mathbf{5 . 0 8}$ \\
\hline $\mathrm{RSO}_{3} \mathrm{H}$ & 7 & 1377.89 & $\mathbf{5 . 0 8}$ \\
$\mathrm{HSO}_{4}^{-}$ & 8 & 1226.5 & $\mathbf{5 . 4 8}$ \\
\hline
\end{tabular}

Figure 11 shows the spectrum of the adsorption of nicotine on BTLs surface. 


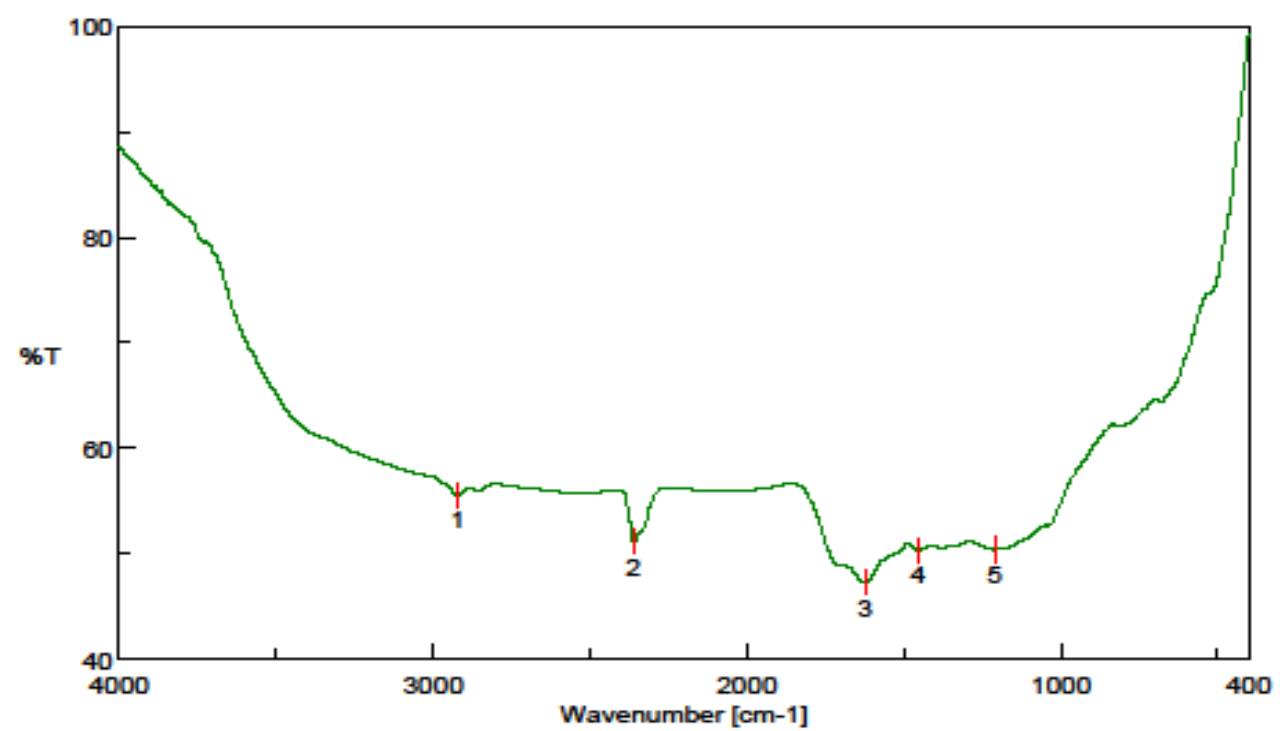

Figure 11. FT-IR spectrum of (BTLS) and the adsorbed nicotine on its surface

The effective functional groups $\left(-\mathrm{NH}_{2}\right.$, $\mathrm{C}=\mathrm{N}$ and $\mathrm{C}=\mathrm{C}$ ) shown in Table (8) indicate the presence of a nicotine molecule $\left(\mathrm{C}_{10} \mathrm{H}_{14} \mathrm{~N}_{2}\right)$ adsorbed on the surface of BTLs. The existence of the $\mathrm{RSO}_{3} \mathrm{H}$ group is evidence for the hydrogen correlation between the nitrogen of the nicotine molecule and the hydrogen atom on the solfonated surface.

Table 8. Effective functional groups in FT-IR spectrum of BTLs and the adsorbed nicotine on its surface (Kzitcina et al., 1979)

\begin{tabular}{cccc} 
Group & Number & The wave number $\mathbf{c m}^{-\mathbf{1}}$ & Intensity \\
\hline$-\mathrm{CH}$ & 1 & 2921.63 & $\mathbf{5 . 5 6}$ \\
\hline $\mathrm{NH}_{3}^{+}$ & 2 & 2360.44 & $\mathbf{5 . 1 1}$ \\
\hline $\begin{array}{c}\mathrm{C}=\mathrm{N} \\
\mathrm{C}=\mathrm{C} \\
-\mathrm{NH}_{2}\end{array}$ & 3 & 1624.73 & $\mathbf{4 . 7 3}$ \\
$\begin{array}{c}\mathrm{S}=\mathrm{O} \\
\mathrm{RSO}\end{array}$ & 5 & 1211.08 & $\mathbf{5 . 0 4}$ \\
\hline
\end{tabular}

\subsection{Mechanism of the adsorption of nicotine on (BTLS)}

The spectral study enabled the assumption of the mechanism of nicotine molecules adsorption.
The detailed format of nicotine signifies that the two atoms of nitrogen are the base of the process of adsorption when considering it as an alkaline molecule, where the ionization constant of the quintet berouliden cycle is $p \mathrm{~K}_{\mathrm{a}}=8.02$. This is 
considered to be more alkaline than the sextet cycle that has an ionization constant of $p \mathrm{~K}_{\mathrm{a}}=3.12$ (Http., 2016), as shown in Figure (12).

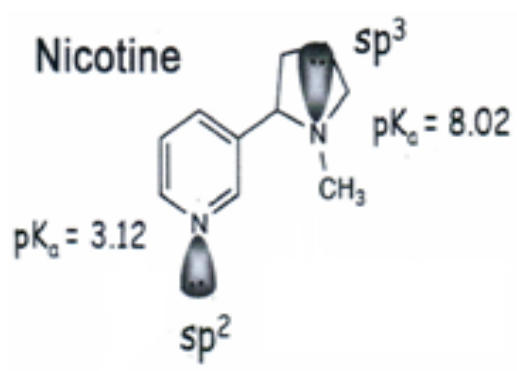

Figure 12. nicotine molecular

The two atoms of nitrogen connect with the protons of the BTLs surface by hydrogen bonds. The atom of nitrogen unconnected with the group $-\mathrm{CH}_{3}$ is the most effective, attributable to its connection with $\pi$ bonds in the part of pyridine of nicotine.<smiles>CN1CC=CC1c1cccn1C</smiles>

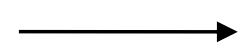<smiles>O=S(=O)(O)CCC(Br)(Br)Br</smiles><smiles>Cn1cccc1C1C=CC=C1</smiles>

The bipolar torque of nicotine molecules equals 2.62 Debye (Osipov et al., 1965). The mechanism of adsorption is shown in Figure (13).

Figure 13. The mechanism of nicotine adsorption

The adsorption of the nicotine molecule is on the Bronsted centers (proton donor) located on BTLs surface, and these factors represent the adsorption of a polar material on a polar surface.

\section{CONCLUSION}

The adsorbed amount of nicotine was determined by measuring the change in its initial concentration at room temperature, spectrophotometrically. An increase of the adsorbed amount correlates with an increase in the initial concentrations at the room temperature. The experimental data corresponded to the adsorption models of Langmuir, Freundlish and Temkin. The order of the surface interaction was determined according to the pseudo secondorder model.

The spectral study (FT-IR) of the sample before and after modifying the 
process with oleum and after the adsorption of nicotine on its modified surface and the appearance of peaks, indicated the influence of modification of the BTLs residual with oleum on the nicotine adsorption on its surface. A mechanism of the nicotine adsorption was suggested to occur with the participation of the two nitrogen atoms.

\section{ACKNOWLEDGMENTS}

This research was funded by the scientific affairs in Damascus University. The authors would like to thank Dr. Hanan Al Chaghouri for her contribution for writing the manuscript in English.

\section{REFERENCES}

Adnan, M., Ahmad, A., Ahmed, A., Khalid, N., Hayat, I., Ahmed, I., (2013). Chemical composition and sensory evaluation of tea (camellia sinensis) commercialized in Pakistan, Pak. J. Bot., 45(3): 901-907.

AlBezreh, W.Y., Shaheen, A., (1999). A study on the adsorption properties of adsorbents for nicotine prepared starting from Syrian Raw materials. A master degree dissertation, Damascus university, Syria, 24-25.

AlBizreh, W.Y., Almostafa, R., AlJoubbeh, M., (2017). Adsorption of nicotine on Sulfonated compressed coffee waste and study of its surface properties. Journal of Sciences, Damascus University, Syria.

Almostafa, R., AlBizreh, W.Y., AlJoubbeh, M., (2017). Sulfonated Carbon of date seeds for nicotine adsorption and ion exchange. Journal of Sciences, Damascus University, Syria.
Altundogan, S.H., Arslan, E.N., Tumen, F., (2007). Copper Removal From Aqueous Solutions By Sugar Beet Pulp Treated By $\mathrm{NaOH}$ And Citric Acid. Journal Of Hazardous Materials, 149, 432-439.

Basher, Z., Gupta, A.K., Chattre, A., (2013). Adsorption Capacity of Nicotine From Tobacco Products By Different Adsorbents. International Journal of Computational Engineering Research, Vol 03, Issue, 11.

Basher, Z., Gupta, A.K., Chattre, A., (2014). Adsorption Isotherm Of Separation Of Nicotine In Tobacco Products By Low Cost Adsorbents. IOSR Journal of Applied Physics (IOSR-JAP), Vol. 3, 39-45.

Belitz, H.D., Grosch, W., Schieberle., (2009). Food chemistry, 4th revised extended edition, Springer-Verlag Berlin Heidelberg, 953.

Dada, A.O., Olalekan, A.P., Olatunya, A.M., Dada, O., (2012). Langmuir, Freundlich, Temkin and DubininRadushkevich isotherms studies of equilibrium sorption of $\mathrm{Zn} 2+$ unto phosphoric acid modified rice husk. IOSR Journal of applied chemistry, $3,38-45$.

Elhadi, H.N., Chattree, A., (2016). Alkaloid removal from popular Indian brands of cigarettes using low cost adsorbents. International Journal of Advanced Research, 4 (11), 565571.

Ghiaci, E.M., Abbaspur, A., Kia, R., Seyedeyn-Azad, F., (2004). Equilibrium isotherm studies for the sorption of benzene, toluene, and phenol onto organo-zeolites and as- 
synthesized. MCM-41. Sep. Purif. Technol. 40, 217-229.

Grozdanic, N., Calado, M., Kijevcanin, M., Šerbanovic, S., Visak, Z., (2014). Aqueous Nicotine Solutions: $\mathrm{pH}$ Measurements And Salting-out Effects-analysis Of The Effective Gibbs Energies Of Hydration And Ionic Strengths Of The Solutions. Serb, Chem Soc, 79 (7), 829-842. http//www.bob-r.com/ENI/nicotine titration notes- $\mathrm{HCl}$.

Ho, Y.S., Me, K.G., (2000). The kinetics of sorption of divalent metal ions onto sphagnum moss peat. water Res, 34 (3), 735-742.

Kzitcina, A., Koupletskayan, B., (1979). Application of UV, IR, NMR and Mass Spectrometry in Organic Chemistry. Moscow University, 169-231.

Lagergren, S., (1998). About the theory of So-called adsorption of soluble substances. Kung Vetensk, Acad, Hand, 24, 1-39.

Maduro, R.M., Aznar, M., (2007). Liquidliquid equilibrium of ternary systems containing nicotine. Issue 1, SPEC. ISS. Fluid Phase Equilib. 259, 83-88.
Novotny, T. E., Zhao, F., (1999). Consumption And Production Waste: Another Externality Of Tobacco Use. Tob. Control 8, 7580.

Osipov, O.A., Minkinv, E., (1965). Hand book of dipole moment. Vishayashcola, Moscow, 164.

Rakic, V., Damjanovic, L., Rac, V., Stosic, D., Dondur, V., Auroux, A., (2010). The adsorption Of Nicotine From Aqueous Solutions On Different Zeolite Structures. water research 44, 2047 - 2057.

Utomo, H.D., (2007). The adsorption of heavy metals by waste tea and coffee residues (Thesis, Doctor of Philosophy). University of Otago. http://hdl.handle.net/10523/159.

Adsorption of heavy metal by waste / Http.

Weber, GR.W., Morris, J.C., (1963). Kinetics of adsorption on carbon from solutions. J.Saint Eng. Div, Am. Soc, civil Eng, 89(2), 31-59. 